\title{
Stop draining the swamp: it's time to tackle wetland loss
}

\author{
Matt Walpole and Nick Davidson
}

Wetlands (including marsh, fen, peatland, lakes, rivers, tidal areas and shallow coastal zones) are amongst the most biodiverse and economically valuable ecosystems (Russi et al., 2013; Costanza et al., 2014). They are also some of the most imperilled, with continuing declines in area, quality and benefits to people (Gardner et al., 2015). Recent estimates suggest an $87 \%$ global decline in natural wetland area since pre-industrial times (Davidson, 2014), losses that persist into the current decade across all continents (Dixon et al., 2016). That wetlands are often in areas of high agricultural productivity or high development pressure-such as coastal areas-has not helped their cause. Yet ultimately wetland loss is a result of a combination of neglect, ignorance and land-use choices that don't fully recognize wetland values, including water and food security and human health.

This issue of Oryx delves into the problems confronting a wide range of wetland-dependent species. Small, fragmented, isolated wetlands are the last refuge for some: for the range-restricted Dades trout in Morocco climate change is likely to reduce suitable habitat (Clavero et al., 2018), and in Asia once-common otters (Li \& Chan, 2018) and fishing cats (Thaung et al., 2018) persist only in remnant populations that often lie outside protected areas.

Relationships between local communities, wetlands and wildlife are often complex. Use of wetland resources can be a safety net for the poorest households yet rising household income can lead to greater resource extraction and wetland degradation (Scales et al., 2018).

Human use of wetlands can bring wildlife into conflict with people. Swamp deer in northern India (Paul et al., 2018), marsh deer in South America (Iezzi et al., 2018), and crocodiles in the Sundarbans (Das \& Jana, 2018) have all been persecuted. Other species are affected by humanfacilitated invasive species: the Vulnerable reticulated flatwoods salamander has declined as a result of feral swine invading its wetland breeding grounds (Jones et al., 2018). Others have been squeezed out: the Critically Endangered Aloatra lemur has been pushed to the brink by the conversion of its marshland home for rice cultivation (Waeber et al., 2018).

\section{Matt Walpole Fauna \& Flora International, Cambridge, UK E-mail matt.walpole@fauna-flora.org}

Nick Davidson Nick Davidson Environmental, Wigmore, UK, and Institute for Land, Water and Society, Charles Sturt University, Albury, New South Wales, Australia
Nevertheless, sustainable wetland management can create positive conditions for wildlife. Incentive-based conservation agreements in Colombia have helped to protect threatened Amazonian fish (Mora et al., 2018), and locallymanaged harvesting of saltwater crocodile eggs in northern Australia has reduced offtake compared with external commercial operations (Corey et al., 2018). Long-term monitoring can also help determine appropriate management interventions. Canova \& Balestrieri (2018) used such an approach to reveal how dredging influenced the breeding cycle of the Italian agile frog.

Restoration is an increasingly important tool for wetland conservation. In Cambridgeshire the Great Fen, one of the most ambitious ecological restoration projects in Europe, is returning drained fenland to its former inundated glory, and wildlife is thriving. Yet even artificial wetlands, which have increased markedly as natural wetlands continue to decline (Davidson et al., 2018), can provide valuable wildlife havens. In one uplifting example, a threatened frog that was presumed extirpated from southern California was rediscovered in artificial ponds on a former trout farm (Backlin et al., 2018). When things become critical, ex situ captive breeding and later reintroduction may be required (Biega \& Martin, 2018).

The plight of wetlands is championed internationally by the Ramsar Convention on Wetlands of International Importance. Originally signed in 1971, it provides a framework for national action and international cooperation in the conservation and wise use of wetlands (Finlayson et al., 2011). Signatories commit to incorporating wetland conservation and wise use into their national development through appropriate policies and actions, and to maintaining the ecological character of designated Ramsar sites, of which there are currently c. 2,300.

Reports from Contracting Parties suggest that designated Ramsar sites are in better condition than others, yet information from the last round of national reporting indicates that $30 \%$ of the global area under Ramsar site designation is deteriorating. If this is the case for the c. $18 \%$ of the world's estimated 12 million $\mathrm{km}^{2}$ of wetlands that have been Ramsar designated (Davidson et al., 2018), it is little wonder that other wetlands are being destroyed or degraded.

Only about half of all Contracting Parties have a national wetland policy. Less than half have a comprehensive national wetland inventory. With respect to threats, only $42 \%$ of Contracting Parties have inventoried invasive species in wetlands and only a third have established national policies 
or guidelines on their control and management. Only just over half of all Ramsar sites have management plans that are being implemented, and only a third of Contracting Parties have a mechanism in place to ensure that negative human impacts on their Ramsar sites are reported.

Moreover, despite close cooperation with other biodiversity-related conventions (Davidson \& Coates, 2011), the Ramsar Convention remains outside the UN-administered multilateral mainstream. Despite being relevant to many of the UN Sustainable Development Goals, wetlands only receive explicit mention in a single target under Goal 6 on water management and another under Goal 15 on conserving terrestrial and inland freshwater ecosystems, neither of which has an agreed means to monitor progress in improving wetland condition.

Although Ramsar has made significant efforts to highlight the multiple values of wetlands to society (exemplified through its theme-based approach to World Wetland Day celebrations), wetland biodiversity remains neglected. Populations of freshwater species have declined by $81 \%$ since 1970, faster than species in any other ecosystem (WWF, 2016).

We know a great deal about how important wetlands are for people, but as a society we have not yet meaningfully acted on wetland loss. We need responses on a much broader scale by fully integrating wetlands into economic policy and decision-making. As governments convene at the Ramsar Conference of Parties in Dubai this month (October 2018), it is time to reverse the neglect of these comparatively small but incomparably valuable areas. Draining the swamp is not the wisest plan...

\section{References}

Backlin, A.R., Richmond, J.Q., Gallegos, E.A., Christensen, C. K. \& Fisher, R.N. (2018) An extirpated lineage of a threatened frog species resurfaces in southern California. Oryx, 52, 718-722.

Biega, A. \& Martin, T.E. (2018) Do amphibian conservation breeding programmes target species of immediate and future conservation concern? Oryx, 52, 723-729.

Canova, L. \& Balestrieri, A. (2018) Long-term monitoring of the endemic Rana Iatastei: suggestions for after-LIFE management. Oryx, 52, 709-717.

Clavero, M., Calzada, J., Esquivias, J., Veríssimo, A., Hermoso, V., Qninba, A. \& Delibes, M. (2018) Nowhere to swim to: climate change and conservation of the relict Dades trout Salmo multipunctata in the High Atlas Mountains, Morocco. Oryx, 52, 627-635.

Corey, B., Webb, G.J., Manolis, S.C., Fordham, A., Austin, B.J., FUKUDA, Y. et al. (2018) Commercial harvests of saltwater crocodile Crocodylus porosus eggs by Indigenous people in northern Australia: lessons for long-term viability and management. Oryx, 52, 697-708.

Costanza, R., De Groot, R., Sutton, P., van der Ploeg, S., Anderson, S.J., Kubiszewski, I. et al. (2014) Changes in the global value of ecosystem services. Global Environmental Change, 26, 152-158.
DAs, C.S. \& JANA, R. (2018) Human-crocodile conflict in the Indian Sundarban: an analysis of spatio-temporal incidences in relation to people's livelihood. Oryx, 52, 661-668.

Davidson, N.C. (2014) How much wetland has the world lost? Long-term and recent trends in global wetland area. Marine and Freshwater Research, 65, 934-941.

Davidson, N.C. \& Coates, D. (2011) The Ramsar Convention and synergies for operationalising the convention on biological diversity's ecosystem approach for wetland conservation and wise use. Journal of International Wildlife Law and Policy 14, 199-205.

Davidson, N.C., Fluet-Chouinard, E. \& Finlayson, C.M. (2018) Global extent and distribution of wetlands: trends and issues. Marine and Freshwater Research, 65, 934-941.

Dixon, M.J.R., Loh, J., Davidson, N.C. \& Walpole, M.J. (2016) Tracking global change in ecosystem area: The Wetland Extent Trends Index. Biological Conservation 193, 27-35.

Finlayson, M.C., Davidson, N., Pritchard, D., Milton, G.R. \& MACKAY, H. (2011) The Ramsar Convention and ecosystem-based approaches to the wise use and sustainable development of wetlands. Journal of International Wildlife Law and Policy, 14, 176198.

Gardner, R.C., Barchiesi, S., Beltrame, C., Finlayson, C.M., Galewski, T., Harrison, I. et al. (2015) State of the World's Wetlands and their Services to People: A Compilation of Recent Analyses. Ramsar Briefing Note no. 7. Ramsar Secretariat, Gland, Switzerland.

Iezzi, M.E., Fracassi, N.G. \& Pereira, J.A. (2018) Conservation of the largest cervid of South America: interactions between people and the Vulnerable marsh deer Blastocerus dichotomus. Oryx, 52, $654-660$.

Jones, K.C., Gorman, T.A., Rincon, B.K., Allen, J., HaAs, C.A. \& ENGEMAN, R.M. (2018) Feral swine Sus scrofa: a new threat to the remaining breeding wetlands of the Vulnerable reticulated flatwoods salamander Ambystoma bishopi. Oryx, 52, 669-676.

LI, F. \& Chan, B.P.L. (2018) Past and present: the status and distribution of otters (Carnivora: Lutrinae) in China. Oryx, 52, 619-626.

Mora, M., Palacios, E. \& Niesten, E. (2018) Assessing the impact of conservation agreements on threatened fish species: a case study in the Colombian Amazon. Oryx, 52, 687-696.

Paul, S., Pandav, B., Mohan, D., Habib, B., Niham, P. \& Mondol, S. (2018) Current distribution and status of the swamp deer Rucervus duvaucelii duvaucelii in the upper Gangetic plains of north India. Oryx, 52, 646-653.

Russi, D., ten Brink, P., Farmer, A., Badura, T., Coates, D., Förster, J. et al. (2013) The Economics of Ecosystems and Biodiversity for Water and Wetlands. Institute for European Environmental Policy, London, UK and Brussels, Belgium, and Ramsar Secretariat, Gland, Switzerland.

Scales, I.R., Friess, D.A., Glass, L. \& Ravaoarinorotsihoarana, L. (2018) Rural livelihoods and mangrove degradation in south-west Madagascar: lime production as an emerging threat. Oryx, 52, 641-645.

Thaung, R., Herranz Muñoz, V., Holden, J., Willcox, D. \& Souter, N.J. (2018) The Vulnerable fishing cat Prionailurus viverrinus and other globally threatened species in Cambodia's coastal mangroves. Oryx, 52, 636-640.

Waeber, P.O., Reibelt, L.M., Randriamalala, I.H., Moser, G., Raveloarimalala, L.M., Ralainasolo, F.B. et al. (2018) Local awareness and perceptions: consequences for conservation of marsh habitat at Lake Alaotra for one of the world's rarest lemurs. Oryx, 52, 677-686.

WWF (2016) Living Planet Report 2016. Risk and Resilience in a New Era. WWF International, Gland, Switzerland. 